\title{
In Vitro Assessment of Nickel Ion Release from Orthodontic Wires
}

\author{
Raoul Bationo $^{1 *}$, Claudia Quilodran-Naudon ${ }^{2}$, Fabienne Jordana ${ }^{3}$, Jacques Colat-Parros ${ }^{2}$ \\ ${ }^{1}$ CHU de Bogodogo, 14 BP 371 Ouagadougou 14, Burkina Faso \\ ${ }^{2}$ UFR des Sciences Odontologiques, 146 Rue Léo Saignat, 33076 Bordeaux, CHU Pellegrin, Bordeaux, France \\ ${ }^{3}$ UFR d'Odontologie de Nantes, 1 Place Alexis Ricordeau, BP 84215, 44042 Nantes cedex 1, France
}

Service d'Odontologie, CHU Nantes, 1 Place Alexis Ricordeau, 44093 Nantes cedex 1, France

*Corresponding Author: Raoul Bationo, CHU de Bogodogo, 14 BP 371 Ouagadougou 14, Burkina Faso. Email: raobat10@yahoo.fr

\begin{abstract}
Most of orthodontic alloys contain nickel. The consumption of acidic drinks may have an impact on these alloys in particular with respect to corrosion resistance. The corrosion is accompanied by nickel ion release that can generate hypersensitivity reactions.

This study will quantify the release of nickel ions from orthodontic wires of stainless steel and nickel-titanium submitted to a bending constraint after a static immersion in acidified medium. Wire segments from NickelTitanium and stainless steel of which some are submitted to a bending constraint are immersed in acid media and then immersion solutions are analyzed using the inductive coupling plasma mass spectrometer (ICP-MS) with a detection threshold of $0.5 p p b(\mu g / L)$. Nickel ions were detected in all analyzed samples. The results range from 2.4ppb to $9404 \mathrm{ppb}$. Even with constraint, the release of nickel would be well below the level of daily food intake. The corrosive behavior depends on the properties of material, the manufacturing process, the environment, the $\mathrm{pH}$ values and the constraints. The surface condition is an important factor for corrosion. More the surface is rougher and the more likely it is to be attacked by corrosion especially by injection corrosion. The manufacturers should take this issue into account.
\end{abstract}

Keywords: Ion release, Nickel-Titanium, Stainless Steel, ICP-MS

\section{INTRODUCTION}

Orthodontics requires the introduction of often metallic devices on the teeth in order to move them. As soon as a bracket or an arch is inserted into the mouth, chemical reactions are set up. The consumption of acidic drinks may have an impact on these devices in particular with respect to corrosion resistance.

The corrosion is accompanied by a loss of material that can have consequences on the body and generate hypersensitivity reactions.

The superficial atomic layers are the first to act with the surrounding environment because they remain reactive from an electronic point of view. Then corrosion can lead gradually to deep alterations in biomaterials.

The corrosion level of any metal depends on the chemical composition of the solvent in which it is immersed [1].

Most of orthodontic alloys contain nickel, varying from $8 \%$ in the stainless steel to more than $50 \%$ in the nickel-titanium alloys; nickel is classified as non-biocompatible and even toxic. The release of nickel ions from these alloys is a concern because of its toxic, immunogenic, mutagenic, local and systemic chemotactic effects [2].

Nickel, a main ingredient of orthodontic materials, can cause severe health hazards in biologic tissues. Hypersensitivity is the most common consequence of exposure to nickelcontaining products, with incidence ranging from $4.5 \%$ to $20 \%$ in the literature [3-6]. The cytotoxic effect of nickel has been shown in cell culture studies [7-9]. Subtoxic levels of nickel are capable of causing DNA strand breaks and DNA base damage [10] and inhibition of DNA lesions repair [11]. Small quantities of nickel ion are capable of activating monocytes and possibly enhance an inflammatory response in soft tissues [9].

Nickel is nevertheless an essential chemical element for normal functioning of the human 
body. The total nickel content of the body of an individual with $75 \mathrm{~kg}$ weight is estimated at about $11 \mathrm{mg}$. The level of daily food intake is $300-$ $500 \mu \mathrm{g}[12]$.

The biocompatibility assessment of orthodontic wires containing nickel is very important and therefore deserves a thorough investigation.

This study will quantify the release of nickel ions from orthodontic wires of stainless steel and nickel-titanium submitted to a bending constraint after a static immersion in acidified medium.

\section{Materials AND Methods}

Four types of maxillary arc wires of $0.016 "$ $(0.041 \mathrm{~cm})$ diameter are used.

- Speed Supercable (Speed System): Coaxial 6 strands, twisted

- Sentalloy (Dentsply GAC): Monostrand

- Co-Ax Steel (American Orthodontics): Twisted, 6 strands

- Stainless Steel (American orthodontics): Monostrand

The ends of the arcs are sectioned in order to obtain wire segments of a length of $5 \mathrm{~cm}$. A Table1. ICP-MS Results

\begin{tabular}{|l|l|c|c|}
\hline & Immersion medium & Concentration of Ni ions (ppb) & $\begin{array}{c}\text { Ion release per unit of } \\
\text { surface }\left(\boldsymbol{\mu g} / \mathbf{c m}^{2}\right)\end{array}$ \\
\hline \multirow{3}{*}{ Speed Supercable } & $\mathrm{H}_{2} \mathrm{O}+\mathrm{HNO}_{3}$ & 9404 & 14.69 \\
\cline { 2 - 4 } & Ringer $+\mathrm{C}_{3} \mathrm{H}_{6} \mathrm{O}_{3}$ & 824.12 & 1.28 \\
\cline { 2 - 4 } & Ringer $\mathrm{C}_{3} \mathrm{H}_{6} \mathrm{O}_{3} *$ & 599.31 & 0.93 \\
\cline { 2 - 4 } & $\mathrm{H}_{2} \mathrm{O}$ & 2.4 & 0.0037 \\
\hline Acier Co-Ax & $\mathrm{H}_{2} \mathrm{O}+\mathrm{HNO}_{3}$ & 12.6 & 0.019 \\
\hline Stainless Steel & $\mathrm{H}_{2} \mathrm{O}+\mathrm{HNO}_{3}$ & 78.4 & 0.12 \\
\hline Sentalloy & $\mathrm{H}_{2} \mathrm{O}+\mathrm{HNO}_{3}$ & 74.8 & 0.11 \\
\hline
\end{tabular}

* No constraint

Nickel ions were detected in all analyzed samples. The results range from $0.003 \mu \mathrm{g} / \mathrm{cm}^{2}$ to $14.69 \mu \mathrm{g} / \mathrm{cm}^{2}$.

The Speed Supercable immersed in $\mathrm{H}_{2} \mathrm{O}+\mathrm{HNO}_{3}$ shows the highest level of nickel ion release. The low concentration of ions is found with distilled water as an immersion medium and there is more release in the inorganic medium $\left(\mathrm{H}_{2} \mathrm{O}+\mathrm{HNO}_{3}\right)$ than in the organic medium (Ringer $+\mathrm{C}_{3} \mathrm{H}_{6} \mathrm{O}_{3}$ ).

So, $\mathrm{pH}$ is an important factor in nickel ion release.

In the same medium (Ringer $+\mathrm{C}_{3} \mathrm{H}_{6} \mathrm{O}_{3}$ ) and for the same type of Nickel-Titanium wire (Speed Supercable) the ion release is higher with the wire submitted to a constraint. This is in line with bending constraint is applied to a segment of each wire using an elastic.

The wire segments are then immersed in $2 \mathrm{~mL}$ of each of three solutions contained in bottles at $37^{\circ} \mathrm{C}$ for 16 days.

- Ringer + lactic acid $\left(\mathrm{C}_{3} \mathrm{H}_{6} \mathrm{O}_{3}\right): 31$ drops for $30 \mathrm{~mL}, \mathrm{pH} 2$

- Distilled water + nitric acid $\left(\mathrm{HNO}_{3}\right): 2$ drops for $30 \mathrm{~mL}, \mathrm{pH} 2$

- Distilled water pH 7

Only some samples will be evaluated because of the high cost of analysis.

Immersion solutions are analyzed using the inductive coupling plasma mass spectrometer (ICP-MS) with a detection threshold of $0.5 \mathrm{ppb}$ $(\mu \mathrm{g} / \mathrm{L})$ in order to quantify nickel ion release.

Nickel ion release per unit of surface is calculated by considering a surface of $0.64 \mathrm{~cm}^{2}$ for each wire segment.

\section{RESUlTS AND DISCUSSION}

ICP-MS results were presented in table 1.

the study of Liu et al. [13], for whom the NickelTitanium arcs submitted to a constraint would release more nickel ions than the not stressed arcs.

The reduced number of samples makes it possible to obtain some descriptive conclusions and observations which do not however have statistical signification.

The results will be discussed in relation to certain aspects of biocompatibility. The release values will be converted to $\mu \mathrm{g} /$ day. In the calculation, a total length of $14 \mathrm{~cm}$ will be considered for each orthodontic arc and therefore the surface is estimated at $3.6 \mathrm{~cm}^{2}$ for upper and lower round arcs. 
The maximum quantity of detected ions (Speed Supercable in $\mathrm{H}_{2} \mathrm{O}+\mathrm{HNO}_{3}$ ) will be $52.88 \mu \mathrm{g}$ for the upper and lower arcs which corresponds to a $3.3 \mu \mathrm{g} /$ day ion release even if one could expect to more release of nickel in the first few days.

This quantity is much lower than the daily food intake (300-500 $\mu \mathrm{g})$ and the critical concentration $(600-2500 \mu \mathrm{g})$ needed to induce an allergy [14]. Arndt et al. [14] used Fusayama artificial saliva + lactic acid with different types of arcs and got a maximum nickel ion release of $8.2 \mu \mathrm{g} /$ day.

According to the US directive limiting the nickel use on the skin $(94 / 27 / \mathrm{CE})$, the amount of released nickel from products intended to enter to direct and extended contact with the skin should not exceed $0.5 \mu \mathrm{g} / \mathrm{cm}^{2} /$ week [15]. It would be possible that the Nickel-Titanium arcs may be the cause of allergic reaction, but this remains a rare phenomenon.

The diffusion of metallic nickel may occur through defective layers of $\mathrm{TiO}_{2}$, which could be the case of layers affected by the constraint. The tension area of the constraint could be victim of micro tear at the surface of the wire, which would favor the release of nickel ions. These areas, with a defective layer of passivation, would be more corrosive [16].

For Briceno et al. [17], the presence of martensite improves corrosion resistance and decreases the release of nickel into the saliva at $37^{\circ} \mathrm{C}$. Because of the number of involved factors, it is difficult to see this in the present study.

The present study was carried out with static conditions in vitro. In clinical conditions the friction between wire and bracket could induce corrosion phenomenon and thus increase the release of nickel ions. The corrosive behavior was very much medium dependent; in vivo tests would allow to have more reliable results. The use of artificial saliva was not possible due to the difficulty of getting a constant acid $\mathrm{pH}$ throughout the study.

The $\mathrm{pH} 2$ of media represents an extreme situation, which should not be clinically met. In vivo, the rate of release should therefore be reduced. Other factors of the medium such as fluorine inducing the corrosion are not taken into account in this study.

\section{CONClusion}

Nickel-Titanium and stainless steel appear to be biocompatible materials for orthodontic treatment and should not present health hazards.
The low release of nickel ions may be a source of concern for allergic patients, but it does not lead to problems in the majority of orthodontic patients because toxic levels are never achieved.

Even with mechanical and thermal constraint, the release of nickel would be well below the level of daily food intake.

The corrosive behavior depends on the properties of material (chemical composition, microstructure), the manufacturing process, the environment, the $\mathrm{pH}$ values and the constraints.

The surface condition is an important factor for corrosion. More the surface is rougher and the more likely it is to be attacked by corrosion especially by injection corrosion. The manufacturers should take this issue into account.

\section{ACKNOWLEDGEMENTS}

We thank team of Technical Investigation Service of University of Alicante in Spain.

\section{REFERENCES}

[1] House K, Sernetz F, Dymock D, Sandy JR, Ireland AJ. Corrosion of orthodontic appliancesshould we care? Am J Orthod Dentofacial Orthop 2008;133(4):584-592

[2] Jacobs JJ, Gilbert JL, Urban RM. Corrosion of metal orthopaedic implants. J Bone Joint Surg Am 1998;80:268-282

[3] Peltonen L. Nickel sensitivity in the general population. Contact Dermatitis 1979;5:27-32

[4] Savolainen H. Biochemical and clinical aspects of nickel toxicity. Rev Environ Health 1996; 11:167-173

[5] Kerosuo H, Kullaa A, Kerosuo E, Kanerva L, Hensten-Pettersen A. Nickel allergy in adolescents in relation to orthodontic treatment and piercing of ears. Am J Orthod Dentofacial Orthop 1996;109:148-154

[6] Menne T. Prevention of nickel allergy by regulation of specific exposures. Ann Clin Lab Sci 1996;26:133-138

[7] Jia W, Beatty MW, Reinhardt RA, Petro TM, Cohen DM, Maze CR, et al. Nickel release from orthodontic arch wires and cellular immune response to various nickel concentrations. J Biomed Mater Res 1999;48:488-495

[8] McKay GC, Macnair R, MacDonald C, Grant $\mathrm{MH}$. Interactions of orthopaedic metals with an immortalized rat osteoblast cell line. Biomaterials 1996;17:1339-1344

[9] Wataha JC, Lockwood PE, Marek M, Ghazi M. Ability of Ni-containing biomedical alloys to activate monocytes and endothelial cells in vitro. J Biomed Mater Res 1999;45:251-257 
[10] Liang R, Senturker S, Shi X, Bal W, Dizdaroglu M, Kasprzak KS. Effects of $\mathrm{Ni}(\mathrm{II})$ and $\mathrm{Cu}(\mathrm{II})$ on DNA interaction with the $\mathrm{N}$-terminal sequence of human protamine $\mathrm{P} 2$ : enhancement of binding and mediation of oxidative DNA strand scission and base damage. Carcinogenesis 1999;20:893898

[11] Eliades T, Zinelis S, Papadopoulos MA, Eliades G, Athanasiou AE. Nickel content of as-received and retrieved NiTi and stainless steel archwires: assessing the nickel release hypothesis. Angle Orthod 2004;74:151-154

[12] Schroeder HA, Balassa JJ, Tipton IH. Abnormal trace metals in man--nickel. J Chronic Dis 1962;15:51-65

[13] Liu IH, Lee TM, Chang CY, Liu CK. Effect of load deflection on corrosion behavior of NiTi wire. J Dent Res 2007;86(6):539-543
[14] Arndt M, Brück A, Scully T, Jäger A, Bourauel C. Nickel ion release from orthodontic NiTi wires under simulation of realistic in-situ conditions. J Mater Sci 2005;40(14):3659-3667

[15] Milheiro A, Kleverlaan C, Muris J, Feilzer A, Pallav P. Nickel release from orthodontic retention wires-the action of mechanical loading and $\mathrm{pH}$. Dent Mater. The Academy of Dental Materials 2012;28(5):548-553

[16] Espinos JP, Fernandez A, Gonzalez-Elipe AR. Oxidation and diffusion processes in nickeltitanium oxide systems. Surface science 1993; 295: 402-410

[17] Briceno J, Romeu A, Espinar E, Liamas JM, Gil FJ. Influence of the microstructure on electrochemical corrosion and nickel release in NiTi orthodontic archwires. Mater Sci Eng C Mater Biol Appl. Elsevier B.V. 2013;33(8) :4989-4993

Citation: Raoul Bationo et al. In Vitro Assessment of Nickel Ion Release from Orthodontic Wires. ARC Journal of Dental science. 2019; 4(4):1-4. doi:dx.doi.org/10.20431/2456-0030.0404001.

Copyright: () 2019 Authors. This is an open-access article distributed under the terms of the Creative Commons Attribution License, which permits unrestricted use, distribution, and reproduction in any medium, provided the original author and source are credited. 